\title{
REVEALING RELATIONSHIP
}

\section{CAPITALISM, DEMOCRACY AND GLOBALIZATION IN CRITICAL LEGAL STUDIES APPROACH}

\author{
FX.Adji Samekto \\ Faculty of Law,Diponegoro University \\ adjisamekto@yahoo.com
}

\begin{abstract}
The dominance of global capitalism is the result of a long historical process in Western Europe since the Enlightenment in the seventeenth century, the philosophers led by a very large influence on the political-economic thought and legal relationship with the state and its citizens.Capitalism and free market mechanisms become increasingly strong with sustained legal concept of rule of law. The principle of the rule of law actually originally not intended to be a means of achieving public objectives or to solve the problems of society such as the problem of poverty. Rule of law is intended to create a stable structure for individuals and businesses associated with economic activities.Linkage between laissez faire, the rule of law is logically implicated in the growth of the view that the existence of the state is to protect the free market. That is phenomena of globalization. The dominance of the rules of law which is intended to facilitate the interests of the free market encourage the implementation of adjustment programs by the state in Third World. As a result, however, it become difficult to realize policies in favor of poverty, meeting basic needs and alignments on the rights of local communities, the embodiment of social justice and environmental protection.
\end{abstract}

Keywords : capitalism, critical legal studies, democracy, globalization

\section{Introduction}

Globalization emerging secular new discourses and affect global awareness of the world in the state and nation. The discourses include: (1) the implementation of democracy and respect for human rights, (2) environmental protection, (3) improvement of standards labor, (4) increasing the role of women, (5) the 
eradication of corruption and suppression of moral ethics to achieve good governance (clean government). In Indonesia, we can see a variety of legislation has been published post-globalization, especially after Indonesian joined the World Trade Organization (WTO) through Act No.7 of 1994. The Act include: Act No. 5 of 1995 on Anti-Unfair Competition; Act No.13 of 2003 on Labour; Act No.14 of 2001 on Patents; Act 7 of 2004 on Water Resources Privatization Policy.

Thus the positive side of globalization is that globalization is accelerating the process of democratization in a country with all the insistence that it causes. Fifth problems above has now become an international concern which is said to be moving towards a global community level with the main trigger of communication technology. At a further level, the concept of citizenship (socially) moves from the citizens of a country become citizens of the world (global community). The implication does not rule out the idea of hegemonic ideas issued by a government, (who later assumed as public consent by the citizens) can be appreciated again by concerned citizens after interacting with the citizens of the world.Multinational Corporation, NGOs, local government and even individuals now play a role in determining the issues that were inspired by the realization of democracy, such as issues of social justice, democracy, labor, gender and the environment. The awareness is then packaged in the form of legislation through the legislative processes in the country.

Roberto M.Unger stated that in fact the jurists of the nineteenth century have sought to create a legal structure that is based on the idea of democracy and the free market, there is a commitment to a democratic republic and the market system as part that must exist in the republic ${ }^{1}$. Thus there is a kind of mutualism symbiosis between the demands of the enactment democracy with free market mechanisms, namely that the free market will benefit if the interests of capitalism

1 Roberto M.Unger, The Critical Legal Studies Movement, Harvard University Press, 1986, p.1 
in the region where demand and supply are guaranteed lasting democracy. Democratic spirit that comes from Western Europe and the United States accepted as a necessity, lead to poorer noise in its implementation in various countries in this era. Demands to democratize cause excessive actions ( redundant) both by residents and by organs of state .

It was like we look at the phenomenon that occurred in Indonesia, especially after the collapse of President Suharto ( 1967-1998). Various chaos caused by the actions of the citizens in the name of democracy, fellow citizens threatens unity of Indonesia . On the other hand efforts to uphold democracy rolled out many different elements in society. So as there are two opposing sides, on the one hand the implementation of ( the demands of ) democracy cause chaos, on the other hand remain there to promote democracy in order to remain upright even though the country is not yet ready in the structure, rules and culture of the country's citizens and organizers. This is because democracy has been accepted as a necessity.

This analysis is based on the critical legal studies that based on the paradigm of critical theory. Critical Legal Studies is one school of thought in jurisprudence developed from realism legal thought. Legal Studies began to be developed in the United States coincided with the convening of Conference on Critical Legal Studies at the University of Wisconsin - Madison in 1977 . Critical Legal Studies develops the ideas and teachings that outline aimed against ( challenges ) or at least review the norms, standards in legal theory and implementation that is derived from what is known as a modern legal system .

In accordance with the perspective in critical theory paradigm, hence ontologically, in this paper the law or rules of law which is meant to uphold democracy conceived as a reality that arises because there are powerful interests behind the rule of law. Epistemologically, the authors not only describe something, but intends to bring awareness that the realization of democracy through the rule of 
law can not be considered as an undisputed necessity, when in actual cause chaos that is detrimental to the interests of the nation and the state. Critical Theory Paradigm is a set of guidelines that guide how researchers see reality ( ontological) , look at the relationship between researches and the object of research (epistemology) and how the research should be done (methodological ). Critics of positivism as a paradigm in the social sciences, conducted by adherents of the Frankfurt School of thought ( Frankfurt School ) that began to exist its presence in 1923 , with developing critical theory. Relating to the definition of critical theory, some opinions as Crozier ( 1991 ), Held ( 1980 ), and Tar ( 1979 ), says that because of critical theory is not " a single or unified approach, " so the notion of critical theory can not be defined in one definition This paper was wrote in socio legal approach which conceptualize law as the independent variable and also the dependent variable. Consequently, a description of democracy which affect the birth of law and doctrinal principles of law, become an integral part of the discussion in this historical approach.

\section{Democracy From Ancient Perspective to Modern Era}

It is inevitable that democratic discourse is a discourse that is born through a long history in Europe which eventually culminated in the French Revolution of 1789. The history of democracy have ups and downs since the Greek era ( BCE), which is constantly in contact with the phenomenon of power of democracy.Plato was a Greek philosopher spawned ideas of law and governance which later became the source of the teachings development of the next period. In the history of world civilization, the great thinkers commonly found from Athens. Their ideas greatly influenced the history of the Western World. Among the thinkers (philosophers), there are several names that are well known: Socrates (469-399 BC) is regarded as the first thinker. Plato (427-347 BC) who was a disciple of Socrates. Furthermore, 
Plato taught Aristotle (384-322 BC). This continuous thinking down greatly influenced the development of the Western World phylosophy.

Plato, of course influenced by the social order of his time, where belief in the power of the deity is very dominant in the concept of human thought in the city-state ( Polis ) of the time. According to Plato, the universe actually has two (2) world : First, the real world ( phenomenon) and the second, an ideal world ( ideos ). For Plato , the ideal world ( ideos) contains ideal things, very good, which is eternal timeless. Existing ideals, sourced from the deity, and should be the guideline for the real world ( phenomenon). The View ( real ) of Plato's hypothetical : In society has decreed the existence of : ( 1 ) those who have wisdom . They called the sophy ( philosopher ). They are the top class in community and should play a role in the government, (2 ) the people who have bravery. They are called Andreia, which consisted of soldiers who guard the country's security role . The Andreia, have no private property, no family, (3) the people who have the role of maintaining the local economy as farmers and artisans. Their position under the philosophers and soldiers. Artisans and farmers not control the city-state ( Polis ). The role of those three class, according to Plato, should be balanced so that the real world ( phenomenon ) can be good ${ }^{2}$.

The problem is who is able to convey ( transfer ) the substance of the ideal world to the real world? Plato says that the power of deity is delivered to humans through " good thoughts that exist in a good spirit " and it is on the sophy ( philosopher ). So the sophy ( philosopher ) serves to transfer the substance that is in the ideos world into the real world. Ideals that had been sourced from the ideos world further should be guidance in real life, so that the laws are sourced from the

2 Arnold J.Toynbee, 1959, Greek Historical Thought : From Homer to the Age of Heraclius, New York: The New American Library, ,p. 129-130 ; Bill Yenne, 2005, 100 Events That Shaped World History ( Translators, Lili Sri Padmavati, Batam Centre : Karisma Publishing Group,p. 30-31 ; Theo Huijbers, 1982 ,Filsafat Hukum Dalam Lintasan Sejarah, Yogyakarta ; Kanisius , p. 12-14 . 
ideos world should also be guidelines that must be adhered to the real world ( phenomenon ). Any violation of the law is a violation, even a sin. So human behavior in the real world must adjust to the law which is based on those ideos. In Plato's view, the law which is then enforced in the real world is a natural law that comes from the truth of the deity that was delivered by the power of the deity in the human mind, through the " merit " of the philosophers. For the author, this is what could be the explanation of the inception of the deductive approach.

In Plato's idea,is the sophy (philosopher) that play a role in the government of the country while maintaining adherence to the law. However, after seeing the reality, Plato then changed his mind by stating that, a country in ideal world never existed (never formed). The city-state ( polis ) in reality is not governed by the sophy (philosopher), but ruled by - at first - by the ruling military (timocracy group) and then taken over by a bunch of rich people in power (oligarchi). Then from the rich people in power, the government was taken over by the common people (democracy). Plato called it a slump. Much more slumped when the citystate (polis) ruled by a single person (tyranny). Such then in Plato's ideal, the sophy ( philosopher) so trusted because it is assumed to have a good mind and soul so that it can take wisdom. So Plato developed deductive approach departs from the belief that the deity is eternal law and contains the truth. Further interpretation that the deity law is good, universal. Therefore facts events must be in accordance with the laws of the deity. Thus be an understanding that deductive reasoning is an approach that " does not respect " the fact that the dynamic and actually constantly evolving.

The thoughts of Plato was followed by Aristotle ( 384-322 BC ) to say, obedience to the law of the city-state ( Polis ) both written and unwritten - that is sourced from a deity - is moral obedience called as a justice. For the sake of that fairness, the law must be obeyed. So it was in the era of Plato and Aristotle, obedience to the law is a necessity, because the law derived from divine truth. In 
the meantime, people are always in a position of helplessness. The laws of nature are written later inspired the birth of the principles of the common law (general principles of law) that originally grew in the Roman era. Lessening the influence of the teachings of the Godhead in the laws of nature have prompted further ahead the rationalizing processes of the areas of life. This is what underlies Western Europe entered the era of rationalism. This era is also known as the Age of Enlightenment ( Enlightenment ) that occurred from 1650 until the early 1800s. The term " Age of Enlightenment " is used as opposed to the term " Dark Age ", which shows the state in which man has been enlightened, freed his mind from the shackles of domination doctrine of the Godhead then enlightened so as to utilize the mind and its ratio to form a social life together.But people within the nation state is still dominated by the absolute power of the ruling king. Monarchy-an absolute monarchy in Europe- consider that sovereignty is an attribute of the absolute power of the ruling king. L' etat c'est moi (I am is the state) is an implication of absolutism idea that held by the ruling kings in European countries such as the time of King Louis XIV of France (1638-1715). Kings power is believed to, or convinced derived from the delegation of the Lord. Therefore, the absolute power of God, so the power of the King is also revealed to be absolute. Any attempt to disturb the power to sue King is contrary to the Law of the Godhead. This view is a reflection remnants of medieval thought which began in the fifteenth century and lasted until around 1650 's.

Entering the XVII century, that theocentric thinking beginning to fade, replaced by schools of thought that considers human reason as the sole source of civilization and progress of mankind. This thought is what marks the spirit of the Rationalism era. In this era emerged new themes regarding the sovereignty of the people and the value of the human person as a subject of law. Major thinkers of that era, among others, John Locke of England (1632-1704), Montesquieu (16891755), Voltaire and Jean Jacques Rousseau (1712 -1778) all three of the French. 
They do not acknowledge the sovereignty of God as the basis of each rule ${ }^{3}$. According to them, the sovereignty of the people is the only true basis. The sovereignty of the people inspired by the view that all people are born equal. No particular person or group because of rank, have special rights to rule. Based on the similarity of community members as human beings and as citizens of the state, based on the belief that no person or group of people who just have the right to rule others, it must be said that the authority to govern the community should be based on assignment or mandate and approval of citizens. This confidence is then expressed in terms of people sovereignty.

Philosopher who has great influence teaching is John Locke (16321704). He is a philosopher of Rational era (Age of Enlightenment) of England who lived during the Glorious Revolution which gave birth to the Parliament in the constitutional monarchy system. According to John Locke, motivation of establishment of the state is to ensure the human rights, especially its property. Therefore, the primary obligation of the state is to protect the lives and property of citizens, should not be more than that. The powers that be in the state is the power delegated by the people. Therefore, the state authority is limited and not absolute. In this context lies the importance of the law. The teachings of John Locke which very important is that the teachings that depart from his denial of sovereignty could exist anywhere. For John Locke, sovereignty only in exist on community as a whole as presented William S.Carpenter: "The great merit of Locke's political theory lies in his denial that sovereignty can exist anywhere except in the community as a whole.. Thus Locke conceives democracy rather as a spirit rather than as a form of government." 4 .

${ }^{3}$ Franz Magnis Suseno, 1991, Etika Politik, Jakarta, Gramedia Pustaka Utama, p.289- 290; Theo Huijbers,supra.no.2, p. 110-115.

${ }^{4}$ William S. Carpenter, 1960, Introduction to John Locke Two Treatises of Civil Government, London, JM Demt and Sons LTd, p. viv-xv. 
The thoughts of John Locke, Voltaire and Montesquieu is what ultimately led to the French Revolution (1789) which has opened a new era, where the people took over the position of power and respect for the person as a legal subject. It can be said that the French Revolution occurred because there is synergy between the power of Bourgeouis, the conditions of injustice that arises due to the arbitrariness of Louis XVI (1754-1792).

With the emergence of the role of the Burg (bourgeouis) then there was a shift in the centers of activity, which was originally hubs are monasteries and royal, turning to the cities as centers of trade with the new concept hegemony also known as capitalism.Injustice especially affected the poor, but they do not have the power like the bourgeouis. The French Revolution overthrew Louis XVI. It was said then that the French Revolution has taken one aspect, namely in terms of the democratic to the system of state government,so that the state used to be absolutely controlled by kings, became a popular national state based on popular sovereignty (popular democracy).

The implications of the enactment of the sovereignty of the people or government power shift from absolute kings into the hands of the people, is proclaiming the concept of democracy in a system of government, where power in the state should be separated into three parts : First, the legislative power or the power to make law; Second, the executive power or the power to run the law; Third, the judicial power or the power to prosecute violators of the law. This separation is essentially to prevent absolutism that leads to arbitrary action. The doctrine of separation of powers was introduced by Montesquieu (1689-1755) is famous as the teachings of Trias Politica. These powers established by the people because the people are sovereign, not the King. It needs to be conveyed is that the outcome of the French Revolution in 1789 turned out to be more and make room for the bourgeoisie to participate in economic life. This means that the French Revolution in 1789 provided benefits to the bourgeouis. 
They are increasingly asserting their rights in order to try and suppress the state not to intervene in the affairs of property rights, and the state must provide space for community to strive. This was the forerunner of the emergence of capitalism in Western Europe. George C.Lodge, quoting from The Oxford English Dictionary defines capitalism as "a system the which favors the existence of capitalist". Understanding of capitalist itself according Lodge is "one who has accumulated capital or has it available for employment in enterprises ". From this definition it is clear that capital accumulation is the main characteristic inherent in the capitalist system ${ }^{5}$.

Domination of global capitalism that dominates the world trade system to date is the result of a long historical process in Western Europe since the Enlightenment Era in the seventeenth century, driven by the great philosophers who led a very large effect on the political-economic thought and legal relationship between the state and its citizens.

From the above description, it can be understood the opinion of Roberto M.Unger which stated that the actual jurists of the nineteenth century have attempted to create a legal structure that is based on the idea of democracy and the free market, there is a commitment to a democratic republic and the market system as part that must exist in the republic ${ }^{6}$. Thus there is a kind of mutualism symbiosis between the demands of the enactment of democratic system with free market mechanisms, namely that the free market will benefit the interests of capitalism if in the region where demand and supply lasting guaranteed by democracy. Based on that then, globalization, as a new form of capitalist expansion, will be going well when in any region grown democracy. That is why since globalization initiated in

5 George C.Lodge, 1995, Managing Globalization in the Age of Interdependence, Johannesburg, Pfeiffer, p.94- 95.

6 Roberto M.Unger, supra,no.1, p. 1 
the 1990s (along with the collapse of the Soviet Union and the end of the Cold War) also revolved around the issue of democratization to the world with the support of the technological means of communication that is capable of spreading democracy issue throughout the world quickly.

When it linked with Roberto M.Unger opinion and analysis, the positive implications of globalization was still much more geared to the interests of capitalism. Thus, in the era of globalization in which the Northern states impose entry into force of the multilateral free market mechanism, then the imposition of the doctrine of democracy which was born from the idea of the French Revolution mentioned above does not always benefit the Third World countries. Third World countries are not ready to accept the requirement to realize democracy. Implementation structure of democracy demanding the fulfillment of the economic establishment are managed either by the state through the market mechanism , which is supported by the legal rules that tend to minimize the role of the state in the administration of the welfare of citizens. Moreover, the spirit of the Third World as in Indonesia is the spirit of collectivism instead of individualism. However, in fact we found that practices of democracy and the legal system which render still refers to the spirit of Western-style democracy. Not to mention the rules of law which bore also refers to Western thinking.Various legislation in Indonesia has been published to facilitate democracy and the free market.

Globalization which was originally expected to encourage the growth of democratic good governance and empowering people, turned out to cause a tendency of poor governance.Causes of poor governance in general stem from domestic issues related to global economic interests are patterned neo- liberal and should be defined in a number of government policies, even if it has negative impact on the environment and humans. Policies to foster accountability, democracy, transparency,enforcement of environmental laws, just do to accommodate donors such as World Bank, IMF, and other institutions involved in 
economic projects and political. Not in question whether things like that can answer the problems of poverty, while institutions, rule of law and culture never prepared adequately.

\section{Conclusion}

There is a strong relationship between capitalism, democracy and globalization. The relation is described as follows : capitalism as a way of thinking that puts the welfare of the individual through the accumulation of profits in the implementation requires very minimal role for the state, and the inevitable domination of the country. The dominance of the state, based on the experience will lead to excess absence of opportunities for people to develop his own without depending on the country. Therefore the power of the state should not be absolute, must be divided to avoid absolutism. To be able to evolve the community are who are equal citizens. It is the community who determine their representatives in government. The interests of the community in the country is that they could live to develop and accumulate their welfare benefits. It is all there in the meaning of democracy.Globalization is essentially the expansion of capitalism, because globalization is a process that occurs after the ideology of the politic-economy capitalism into a "winner" in the competition of communist versus capitalist economic system, from 1945 to 1989.

Since the globalization is identic with the expansion of capitalism, the characteristics and demands to perpetuate capitalism must be embodied in globalization. The demands include: minimization of the role of the state, free trade, anti-monopoli, respect intellectual property rights, respect for human rights and democracy in governance. When the originator of the globalization dominate the world, then the ideas of globalization with its demands further justification of the Third World countries,countries that are not economically and politically powerful. Even for the sake of getting aid from donor countries,Third World 
Countries willing to make adjustments laws that facilitate the free market, even if it is contrary with their constitutions. The things that appear as democratic awareness should not be explained easily as something that is sure to bring prosperity, because it can not be denied however that the democracy which then manifests itself in a variety of legal rules, can contain pros, though it is said to have accepted as truth.Conclusions about the relation of capitalism, globalization and democracy from the perspective of critical legal studies would be different if discussed in positivism perspective, since each paradigm (critical theory and positivism) has a foundation of ontology and epistemology that is different. The synergy of discussion from the perspective of critical legal studies with positivism would give a balanced discussion, so it is useful to build a new construction of meaning of democracy that increasingly reflects on social justice.

\section{Reference}

C.Lodge, George, 1995, Managing Globalization in the Age of Interdependence, Pfeiffer, Johannesburg.

Cheney, L.J., 1959, A History of the Western World: From the Stone Age to the Twntieth Century, New York: Published by The New American Library.

Carpenter, Wlliam S. ,1960,Introduction to : John Locke, Two Treatises of Civil Government, J.M Demt and Sons,LTd, London.

Wignyosoebroto, Soetandyo, 2000, "Doktrin Supremasi Hukum : Sebuah Tinjauan Kritis Dari Perspektif Historik", Selected Article in, Wajah Hukum Di Era Reformasi, (Selected Articles Devoted to 70 Years of Satjipto Rahardjo), (editor : IS Susanto and Bernanrd L.Tanya), Bandung; Alumni.

Suseno, Franz Magnis, 1991, Etika Politik, Jakarta; Gramedia Pustaka Utama.

Huijbers, Theo, 1981,Filsafat Hukum Dalam Lintasan Sejarah, Yogyakarta, Kanisius.

Toynbee, Arnold J., 1959, Greek Historical Thought : From Homer to the Age of Heraclius, New York; The New American Library.

Yenne, Bill, 2005, 100 Events That Shaped World History (Translator : Lili Sri Padmawati), Batam Centre : Karisma Publishing Group.

Unger, Roberto M. 1986, The Critical Legal Studies Movement, Harvard University Press. 
Revealing Relationship Capitalism, Democracy And Globalization In Critical Legal Studies Approach

Roffer, Michael H.,2015, Law Book : From Hammurabi to the International

Criminal Court,250 Milestones in the History of Law,New York ; Sterling. 